\title{
ANALISIS PERBEDAAN PEMBELIAN IMPULSIF DITINJAU DARI GENDER KONSUMEN PADA PUNCAK TOSERBA BENGKULU
}

\author{
Ida Anggriani, Fera Indasari \\ Fakultas Ekonomi Universitas Dehasen Bengkulu \\ Fakultas Ilmu-ilmu Sosial Universitas Dehasen Bengkulu \\ ida anggriani@yahoo.com \\ Fera.Mugh4al@Gmail.com
}

\begin{abstract}
ABSTRAK
Ida Anggriani, Fera Indasari; Tujuan penelitian ini adalah untuk mengetahui adanya perbedaan pembelian impulsif ditinjau dari gender konsumen pada Puncak Toserba Bengkulu. Jenis penelitian adalah penelitian komparatif, dilakukan untuk membandingkan persamaan dan perbedaan dua atau lebih fakta-fakta dan sifat-sifat objek yang diteliti berdasarkan kerangka pemikiran tertentu. Responden penelitian ini sebanyak 100 orang terdiri dari 50 orang laki-laki dan 50 orang perempuan, sampel diambil dengan teknik purposive random sampling. Pengumpulan data menggunakan kuesioner dengan beberapa alternatif pilihan jawaban yaitu dan metode analisis dengan cara deskriptif dan analisis kuantitatif menggunakan uji independent samplest tes. Metode Pengolahan data menggunakan SPSS versi 19 for windows. Hasil penelitian ini menunjukkan bahwa ada perbedaan yang signifkan antara pembelian impulsif gender laki-laki dan gender perempuan pada Puncak Toserba Bengkulu dengan perbandingan $t_{\text {sig }}$ $(0,047)<\alpha(0,05)$. Perbedaan rata-rata kedua kelompok tersebut sebesar 1,520 berkisar antara 0,019 sampai 3,021.
\end{abstract}

\section{ABSTRACT}

Ida Anggriani, Fera Indasari; The purpose of this study was to the differences in terms of impulsive buying gender determine consumers at Puncak Toserba Bengkulu. This type of research is a comparative study, carried out to compare the similarities and differences of two or more of the facts and object properties in the framework based on certain carefully. Survey respondents as many as 100 people composed of 50 men and 50 women, samples were taken by purposive random sampling technique. Data collection using questionnaire and analysis methods by means of descriptive and quantitative analyzes using independent samples $t$ test trials. Results of this study indicate that there are differences between the purchase impulsive significant gender beetween men and women at Puncak Toserba Bengkulu by comparison Tsig $(0,047)<\alpha$ $(0,05)$. The average difference for the two groups were between to 1,520 ranged 0,019 until 3,021.

Keywords: Impulsive Buying, Gender

\section{PENDAHULUAN}

Pemasaran merupakan ujung tombak perusahaan dalam mencapai tujuan bisnisnya seperti bertahan hidup, memperoleh keuntungan dan berkembang. Tujuan tersebut akan dapat dicapai manakala perusahaan mampu menciptakan, mengantarkan serta mengkomunikasikan nilai melalui sebuah produk yang dijual sehingga dapat meraih maupun mempertahankan pelanggan. Pemahaman tentang bagaimana konsumen menanggapi tawaran perusahaan, memilih serta memutuskan produk yang akan dibeli adalah merupakan kunci sukses dalam pencapaian tujuan perusahaan. Pada kondisi sekarang ini dengan adanya tuntutan waktu yang semakin sempit serta bergesernya budaya maka waktu yang tersedia untuk berbelanja alat pemenuhan kebutuhan sehari-hari juga berubah. Didalam memilih tempat berbelanja biasanya pembeli menghendaki tempat yang tidak terlalu jauh dari tempat tinggal, cukup strategis untuk dilalui dan mudah untuk dicapai apabila ada kebutuhan yang mendesak, kebutuhan yang mendesak, tempat parkir yang luas, menyediakan barang yang serba ada atau lengkap untuk kebutuhan sehari-hari. Jika kondisi tersebut terpenuhi tentunya konsumen akan sering berbelanja pada toko atau usaha tersebut karena belanja merupakan aktivitas yang menyenangkan bagi banyak orang dan sebagian orang tidak dapat dipisahkan dari kebiasaan belanja. Hal ini tidak hanya terbatas pada kaum perempuan, kaum lakilaki, miskin, kaya, berpenghasilan tinggi, berpenghasilan rendah, semuanya punya peluang untuk jadi sasaran. Umumnya orang memiliki kebiasaan berbelanja untuk memenuhi kebutuhan. Meskipun demikian, sering juga ditemui orang yang berbelanja hanya untuk memenuhi hasrat atau dorongan dari dalam dirinya. Pada mulanya belanja hanya merupakan suatu konsep untuk menunjukkan suatu sikap untuk mendapatkan barang yang menjadi keperluan sehari-harinya dengan jalan menukarkan sejumlah uang sebagai pengganti barang tersebut. 
Pada saat ini konsep belanja telah berkembang sebagai sebuah cerminan gaya hidup dan rekreasi di kalangan masyarakat. Belanja adalah suatu gaya hidup tersendiri, dimana bahkan telah menjadi suatu kegemaran bagi sejumlah orang (Tambunan, 2007:22). Belanja menjadi alat pemuas keinginan akan barang-barang yang sebenarnya tidak mereka butuhkan, akan tetapi karena pengaruh trend atau mode yang tengah berlaku, maka mereka merasa merupakan suatu keharusan untuk membeli barang-barang tersebut. Banyak sekali orang yang berbelanja tanpa disertai pertimbangan. Mereka hanya membeli produk-produk yang sebenarnya tidak dibutuhkan dengan alasan sering tidak tahan melihat barang bagus, ingin segera membelinya, dan merasa seperti dibius dan tidak dapat berpikir jernih sehingga yang terdapat di dalam benak individu adalah hanya ingin memuaskan keinginan belanja (Fitri, 2006:6).

Pada umumnya proses belanja dilakukan di dalam pasar modern seperti supermarket atau hipermarket, tidak semuanya direncanakan (Negara dalam Semuel, 2007:28). Dalam segi perencanaan, pembelian konsumen bisa dikategorikan ke dalam pembelian terencana dan pembelian tidak terencana (pembelian impulsif). Pembelian terencana adalah perilaku pembelian dimana keputusan tentang item yang akan dibeli telah diambil sebelum konsumen masuk ke dalam toko. Sedangkan pembelian tidak terencana atau impulsif adalah perilaku pembelian dimana konsumen tidak mempertimbangkan untuk membeli, atau mempertimbangkan untuk membeli tetapi belum memutuskan produk apa yang akan dibeli (Dony, 2007:19).

Terencana atau tidaknya pembelian oleh konsumen telah menjadi perhatian peneliti dan praktisi sejak dua puluhan tahun yang lalu. Kebanyakan orang tertarik untuk meneliti karakteristik dan proporsi konsumen yang melakukan pembeliannya secara terencana dan tidak terencana. Pada kenyataannya konsumen seringkali tidak menggunakan pikiran rasionalnya dalam menentukan barang yang benarbenar dibutuhkannya. Konsumen membeli produk dengan berbagai alasan, seperti; untuk menghilangkan suasana hati yang buruk, mengekspresikan identitas atau hanya untuk bersenang-senang. Gaya membeli yang tidak rasional ini, selalu dihubungkan dengan berbagai macam emosi, seperti kegembiraan atau penyesalan, tapi emosi ini dapat juga menjadi bagian dari pembelian yang tidak terencana yang dikenal dengan pembelian impulsif.

Engel dan Blacwell (2005:62), mendefinisikan pembelian impulsif sebagai suatu tindakan pembelian yang dibuat tanpa direncanakan sebelumnya atau keputusan pembelian dilakukan pada saat berada didalam toko. Sejalan dengan hal itu, pembelian impulsif juga seringkali diasosiasikan dengan pembelian yang dilakukan dengan tiba-tiba dan tidak direncanakan, dilakukan di tempat kejadian, dan disertai timbulnya dorongan yang besar serta perasaan senang dan bergairah.

Dalam pandangan ini terdapat lima elemen penting yang membedakan tingkah laku konsumen yang impulsif dan yang tidak, yaitu; (1) dorongan tiba-tiba dan spontan untuk melakukan tindakan yang berbeda dengan tingkah laku sebelumnya, (2) Dorongan tiba-tiba untuk melakukan pembelian menempatkan konsumen dalam keadaan ketidakseimbangan secara psikologis, (3) Mengalami konflik psikologis dan berusaha menimbang antarapemuasan kebutuhan langsung dan konsekuensi jangka panjang dari pembelian, (4) Mengurangi evaluasi kognitif dari produk, (5) Seringkali membeli secara impulsif tanpa memperhatikan konsekuensi yang akan datang (Loudon dan Bitta, 2003:29).

Karakteristik demografis yang mempengaruhi pembelian impulsif yaitu salah satunya adalah gender (Loudon dan Bitta, 2003:29). Berbagai penelitian mengenai pembelian impulsif yang terkait dengan gender telah dilakukan. Rook dan Hoch (dalam Kacen, 2007) juga menemukan bahwa perempuan lebih cenderung melakukan pembelian impulsif dibandingkan laki-laki. Begitu juga dengan hasil penelitian Ling dan Lin (dalam Semuel, 2007:30) menemukan bahwa perempuan lebih cenderung memiliki perilaku pembelian impulsif dibandingkan laki-laki.

Penelitian ini dilakukan pada Puncak Toserba Bengkulu yang letaknya strategis di lintasan jalan protokol di Kota Bengkulu yang berada diantara Toko-Toko maupun Minimarket yang menjadi kompetitor bagi Puncak Toserba Bengkulu. Barang-barang yang dijual di Puncak Toserba Bengkulu adalah barang-barang yang merupakan kebutuhan sehari-hari baik itu makanan, alat rumah tangga, kosmetik, tas, pakaian pria dan wanita, maupun barang-barang penunjang kebutuhan lainnya, hanya saja Puncak Toserba Bengkulu tidak menjual sayuran dan daging segar, tetapi kalau daging olahan dan kemasan juga dijual Puncak Toserba Bengkulu. Berdasarkan survey yang dilakukan diketahui bahwa sejak awal dibukanya Puncak Toserba Bengkulu telah diminati konsumen sebagai toko terlengkap yang dapat memenuhi kebutuhan hidup konsumen, karena Puncak Toserba Bengkulu dinilai dapat menyediakan apa yang menjadi kebutuhan konsumen dengan lengkap yang berada disekitar kawasan Simpang Lima Kota Bengkulu.

Berdasarkan uraian di atas maka peneliti tertarik mengadakan penelitian mengenai pembelian impulsif di Puncak Toserba Bengkulu dengan judul "Analisis Perbedaan Pembelian Impulsif ditinjau dari Gender Konsumen Pada Puncak Toserba Bengkulu”. 


\section{LANDASAN TEORI \\ Perilaku Konsumen}

Menurut Swastha dalam Daryanto dan Setyobudi (2014:86) menyebutkan bahwa konsumen membeli barang dan jasa adalah untuk memuaskan bcrbagai keinginan dan kebutuhan. Barang dan jasa itu sendiri tidaklah sepenting kebutuhan dan keinginan manusia yang dipenuhinya, melainkan karena barang-barang terscbut dianggap dapat memenuhi kebutuhan yang diinginkanya. Jadi, yang dibeli konsumen bukanlah barangnya sendiri, tetapi kcgunaan yang dapat diberikan barang tersebut, atau dcngan kata lain, kemampuan barang tersebut untuk memenuhi kcbutuhan dan keinginan.

Perilaku konsumen pada hakikatnya untuk memahami "Mengapa konsumen melakukan dan apa yang mereka lakukan". Schiffman dan Kanuk (2008:6) mengemukakan bahwa studi perilaku konsumen adalah suatu studi mengenai bagaimana seorang individu membuat keputusan untuk mengalokasikan sumber daya yang tersedia (waktu, uang, usaha, dan energi). Konsumen memiliki keragaman yang menarik untuk dipelajari karena ia meliputi seluruh individu dari berbagai usia, latar belakang budaya, pendidikan, dan keadaan sosial ekonomi lainnya. Oleh karena itu, sangatlah penting untuk mempelajari bagaimana konsumen berperilaku dan faktor-faktor apa saja yang mempengaruhi perilaku tersebut.

Definisi perilaku konsumen menurut Kotler dan Keller (2008:214) adalah adalah studi bagaimana individu, kelompok dan organisasi memilih, membeli, menggunakan dan menempatkan barang, jasa, ide atau pengalaman untuk memuaskan keinginan dan kebutuhan mereka sedangkan definisi perilaku konsumen menurut Schiffman dan Kanuk (2008:6) menggambarkan cara individu mengambil keputusan untuk memanfaatkan sumber daya mereka yang tersedia (waktu, uang, usaha) guna membeli barang-barang yang berhubungan dengan konsumsi.

Dari pengertian tentang perilaku konsumen di atas dapat diperoleh dua hal yang penting, yaitu: (1) sebagai kegiatan fisik dan (2) sebagai proses pengambilan keputusan. Berdasarkan beberapa definisi yang telah disebutkan di atas dapat disimpulkan bahwa perilaku konsumen adalah semua kegiatan tindakan, serta proses psikologis yang mendorong tindakan tersebut pada saat sebelum membeli, ketika membeli, menggunakan, menghabiskan produk dan jasa setelah melakukan hal-hal di atas atau kegiatan mengevaluasi.

Ada beberapa macam definisi spesifik mengenai perilaku konsumen menurut Daryanto dan Setyobudi (2014:86), diantaranya sebagai berikut: Perilaku konsumen adalah aktivitas-aktiivitas individu dalam pencarian, pengevaluasian, pemerolehan, pengonsumsi, dan penghentian pemakaian barang dan jasa. Perilaku konsumen adalah studi mengenai proses-proses yang terjadi saat individu atau kelompok penyeleksi, membeli, menggunakan, atau menghentikan pemakaian produk, jasa, ide, atau pengalaman dalam rangka memuaskan keinginan dan hasrat tertentu. Perilaku Konsumen adalah perilaku yang ditunjukkan oleh konsumen dalam mencari, membeli, menggunakan, mengevaluasi, dan menghentikan konsumsi produk, jasa, dan gagasan.

Menurut Kotler (2008:25) faktor-faktor yang mempengaruhi perilaku konsumen adalah:

1. Faktor Kebudayaan. Faktor kebudayaan berpengaruh luas dan mendalam terhadap perilaku konsumen. Faktor kebudayaan terdiri dari: budaya, sub-budaya, kelas sosial,

2. Faktor Sosial. Selain faktor budaya, perilaku seorang konsumen dipengaruhi oleh faktor-faktor sosial seperti kelompok acuan, keluarga serta status sosial.

3. Faktor Pribadi. Faktor pribadi yang memberikan kontribusi terhadap perilaku konsumen terdiri dari: usia dan tahap siklus hidup, pekerjaan dan lingkungan ekonomi, gaya hidup, kepribadian dan konsep diri.

4. Faktor Psikologis. Pilihan pembelian seseorang dipengaruhi oleh empat faktor psikologi utama yaitu motivasi, persepsi, pembelajaran, serta keyakinan dan pendirian.

\section{PEMBELIAN IMPULSIF}

\section{a. Pengertian Pembelian Impulsif}

Dalam melakukan keputusan pembelian biasanya ada dorongan yang didasarkan keinginan atau untuk pemuasan baik secara sadar maupun tidak sadar yang disebut impulsif. Menurut Amir (2004:119) pembelian impulsif adalah kecenderungan konsumen untuk melakukan pembelian secara spontan, tidak terefleksi, secara terburu-buru dan didorong aspek psikologis emosional terhadap suatu barang dan tergoda atas ajakan pasar. Perilaku pembelian impulsif banyak didominan wanita, hal ini dapat dipahami karena dalam melakukan pembelian barang proses pengambilan keputusannya banyak dipegang wanita. Sedangkan Pikiran manusia memiliki ide-ide dan rangsangan yang kadangkadang bersifat sadar dan kadang-kadang berada dibawah sadar yang mempengaruhi perilaku pembelian. Manusia tidak menyadari seluruh motif mereka dan hal tersebut menerangkan mengapa para konsumen seringkali tidak menyadari atau tidak menunjukkan alasan-alasan riil/nyata mereka 
mengapa mereka membeli atau tidak membeli. Para pemasar menyimpulkan adanya terdapat perbedaan luas antara apa yang dinyatakan orang-orang akan dibeli dan apa yang sebenarnya mereka beli. Pembeli tidak terencana berarti kegiatan menghabiskan uang yang tidak terkontrol, kebanyakan kepada barang-barang yang sebenarnya tidak terlalu diperlukan (Winardi, 2004:176).

Pembelian tidak terencana mempunyai dasar pertimbangan yang masuk akal. Sistem penjualan dengan pelayanan sendiri (self service) dan tata ruang yang terbuka (open display) akan menimbulkan situasi pemasaran dimana perencanan dapat ditunda sampai pembeli masuk ke dalam toko (Setiadi, 2003:356).

\section{b. Penggolongan Pembelian Impulsif}

Menurut Hawkins Stren dalam Winardi (2004:226), pembelian impulsif dapat digolongkan sebagai berikut:

1. Pembelian tidak terencana murni (pure impulsive buying)

Suatu pembelian yang murni disebabkan oleh suatu pola pembelian yang menyimpang dari pembelian normal. Pada proses impulsif murni, maka calon pembeli langsung mengarahkan kepada suatu merek tertentu dan kemudian melakukan pembelian secara cepat. Kebutuhan akan kategori barang tersebut mungkin timbul di bawah sadar. Dimana tidak ada informasi yang dicari dan tidak ada merek lain yang dipertimbangkan.

2. Pembelian tidak terencana karena pengalaman masa lalu (reminder buying)

Pembelian ini terjadi ketika seseorang pembeli "diingatkan" oleh sebuah stimulus atau rangsangan yang timbul setelah berada di dalam toko yang bersangkutan.

3. Pembelian tidak terencana yang timbul karena sugesti

Pembelian tidak terencana ini terjadi apabila konsumen yang bersangkutan baru pertama kali melihat barang tersebut dimana kualitas, fungsi dan kegunaan barang tersebut sesuai dengan apa yang diharapkannya.

4. Pembelian tidak terencana yang disebabkan situasi tertentu

Pembelian tidak terencana ini terjadi pada saat pusat perbelanjaan melakukan promosi seperti pemberian potongan harga ataupun pemberian kupon berhadiah

\section{c. Elemen Pembelian Impulsif}

Loudon dan Bitta (2003:29) mengemukakan lima elemen penting yang membedakan tingkah laku konsumen yang impulsif dan yang tidak. Elemen-elemen tersebut adalah :

1. Konsumen merasakan adanya suatu dorongan yang tiba-tiba dan spontan untuk melakukan suatu tindakan yang berbeda dengan tingkah laku sebelumnya.

2. Dorongan tiba-tiba untuk melakukan suatu pembelian menempatkan konsumen dalam keadaan ketidakseimbangan secara psikologis, dimana untuk sementara waktu ia merasa kehilangan kendali.

3. Konsumen akan mengalami konflik psikologis dan ia berusaha untuk menimbang antara pemuasan kebutuhan langsung dan konsekuensi jangka panjang dari pembelian.

4. Konsumen akan mengurangi evaluasi kognitif dari produk.

5. Konsumen seringkali membeli secara impulsif tanpa memperhatikan konsekuensi yang akan datang.

Elemen-elemen tersebut secara umum dapat dikelompokkan menjadi dua elemen pokok, yaitu kurangnya perencanaan dan pemikiran yang matang dalam pembelian produk yang dilakukan secara impulsif dan adanya respon emosi yang muncul sebelum, bersamaan, ataupun sesudah pembelian yang tidak direncanakan.

d. Tipe-tipe Pembelian Impulsif

Seperti tertulis diatas, pembelian impulsif merupakan pembelian yang tidak secara khusus direncanakan. Loudon dan Bitta (2003:32) mengemukakan empat tipe dari pembelian impulsif. Keempat tipe pembelian impulsif tersebut adalah sebagai berikut :

1. Pure Impulse

Dalam pembelian impulsif jenis ini, pembeli tidak mengikuti pola pembelian yang biasa ia lakukan (membeli tanpa melakukan pertimbangan).

2. Suggestion Impulse

Dalam kategori pembelian impulsif jenis ini pembeli tidak mengetahui mengenai suatu produk tetapi mungkin memerlukannya ketika pertama kali melihat produk tersebut.

3. Reminder Impulsif

Pada pembelian impulsif jenis ini, pembeli melihat suatu produk dan teringat bahwa stok dirumah sudah perlu dibeli.

4. Planned Impulse 
Dalam pembelian impulsif kategori ini, pembeli memasuki toko dengan harapan dan intensi untuk melakukan transaksi pembelian berdasarkan harga khusus, kupon dan kesukaan.

\section{e. Faktor-faktor yang Mempengaruhi Pembelian Impulsif}

Jumlah yang terbatas dari penelitian tentang pembelian-pembelian yang tidak direncanakan menunjukkan bahwa ada beberapa karakteristik produk, karakteristik pemasaran dan karakteristikkarakteristik konsumen yang muncul sehubungan dengan proses pembelian (Loudon \& Bitta, 2003:35).

1. Karakteristik produk yang mempengaruhi pembelian impulsif adalah :
a) Memiliki harga yang rendah
b) Adanya sedikit kebutuhan terhadap produk tersebut
c) Siklus kehidupan produknya pendek
d) Ukurannya kecil atau ringan
e) Mudah disimpan.

2. Pada faktor marketing, hal-hal yang mempengaruhi pembelian impulsif adalah :

a) Distribusi massa pada self-service outlet terhadap pemasangan iklan besar- besaran dan material yang akan didiskon. Ketersediaan informasi dimana hal ini meliputi suatu format, yang secara langsung berhubungan dengan penggunaan informasi. Bagaimanapun juga, terlalu banyak informasi dapat menyebabkan informasi yang berlebihan dan penggunaan informasi yang kurang. Pemasangan iklan, pembelian barang yang dipamerkan, websites, penjaga toko, paket-paket, konsumen lain, dan sumber yang bebas seperti laporan konsumen adalah sumber utama dari informasi konsumen.

b) Posisi barang yang dipamerkan dan lokasi toko yang menonjol turut mempengaruhi pembelian impulsif. Bahwa jumlah, lokasi dan jarak antara toko barang eceran di pasar mempengaruhi jumlah kunjungan konsumen ke toko sebelum pembelian. Karena kunjungan ke toko membutuhkan waktu, energi, dan uang, jarak kedekatan dari toko seringkali akan meningkatkan aspek ini dari pencarian di luar.

3. Karakteristik konsumen yang mempengaruhi pembelian impulsif adalah :

a) Kepribadian konsumen

b) Demografis, karakteristik demografis terdiri dari gender, usia, status perkawinan, pekerjaan dan pendidikan.

c) Karakteristik-karakteristik sosio-ekonomi yang dihubungkan dengan tingkat pembelian impulsif.

\section{Gender}

\section{a. Pengertian Gender}

Gender berkaitan dengan sosialisasi yang diberikan kepada perempuan dan laki-laki. Perempuan dan laki-laki dibedakan atas dasar kepantasannya kemudian dibuatkan label yang ditempelkan kepada masing-masing jenis untuk membedakan (Murniati, 2004:14). Konsep gender adalah suatu sifat yang melekat pada kaum laki-laki dan perempuan yang dikonstruksi baik secara sosial maupun kultural (Murniati, 2004:197). Oleh karena itu gender berbeda dengan jenis kelamin. Jenis kelamin hanya melihat perempuan dan laki-laki berdasarkan fungsi biologis. Perbedaan perempuan dan laki-laki tersebut tidak dapat dipertukarkan karena berhubungan dengan keadaan alamiah manusia. Berbeda dengan jenis kelamin, peran gender dapat dipertukarkan karena peran tersebut berhubungan dengan budaya dan konvensi dalam masyarakat.

Konsep gender adalah sifat yang melekat pada kaum laki-laki dan perempuan yang dibentuk oleh faktor-faktor sosial maupun budaya, sehingga lahir beberapa anggapan tentang peran sosial dan budaya laki-laki dan perempuan, bentukan tersebut antara lain perempuan dikenal sebagai makhluk yang lemah lembut dan keibuan sedangkan laki-laki dianggap kuat dan rasional (Handayani, 2001:4). Oleh karena itu, gender dapat diartikan sebagai konsep sosial yang membedakan peran antara lakilaki dan perempuan. Perbedaan fungsi dan peran antara laki-laki dan perempuan itu tidak ditentukan karena antara keduanya terdapat perbedaan biologis dan kodrat, tetapi dibedakan atau dipilah-pilah menurut kedudukan, fungsi dan peranan masing-masing dalam berbagai bidang kehidupan dan pembangunan (Handayani, 2001:4).

Gender tidak dibedakan dengan jenis kelamin, akan tetapi jika dilihat dari akar katanya gender memiliki akar kata genos, berasal dari bahasa Yunani yang artinya ras, persediaan, dan keturunan anak. Sesuai dengan akar katanya genos menyiratkan sifat dasar individual khas dan berlainan satu sama lain. Gender lebih berkaitan dengan isu dan konflik psikologis dan budaya daripada biologis(Bagus, 2002:276). 
Gender melihat perbedaan laki-laki dan perempuan berdasarkan kesepakatan atau konvensi masyarakat yang berhubungan dengan perilaku, dan tanggung jawab sosial yang dibentuk oleh masyarakat Gender merujuk pada definisi sosial budaya dari laki-laki dan perempuan, cara masyarakat membedakan laki-laki dan perempuan serta memberikan peran sosial kepada mereka.

\section{b. Teori Dasar tentang Gender}

\section{Teori Kodrat Alam}

Menurut teori ini perbedaan biologis yang membedakan jenis kelamin dalam memandang gender (Suryadi dan Idris, 2004:50). Teori ini dibagi menjadi dua yaitu:

a) Teori Nature

Teori ini memandang perbedaan gender sebagai kodrat alam yang tidak perlu dipermasalahkan

b) Teori Rekayasa Budaya

Teori ini lebih memandang perbedaan gender sebagai hasil rekayasa budaya dan bukan kodrati, sehingga perbedaan gender tidak berlaku universal dan dapat dipertukarkan

2. Teori kebudayaan

Teori ini memandang gender sebagai akibat dari konstruksi budaya (Suryadi dan Idris, 2004:50). Menurut teori ini terjadi keunggulan laki-laki terhadap perempuan karena konstruksi budaya, materi, atau harta kekayaan. Gender itu merupakan hasil proses budaya masyarakat yang membedakan peran sosial laki-laki dan perempuan. Pemilahan peran sosial berdasarkan jenis kelamin dapat dipertukarkan, dibentuk dan dilatihkan.

3. Teori Fungsional Struktural

Berdasarkan teori ini munculnya tuntutan untuk kesetaraan gender dalam peran sosial di masyarakat sebagai akibat adanya perubahan struktur nilai sosial ekonomi masyarakat. Dalam era globalisasi yang penuh dengan berbagai persaingan peran seseorang tidak lagi mengacu kepada norma-norma kehidupan sosial yang lebih banyak mempertimbangkan faktor jenis kelamin, akan tetapi ditentukan oleh daya saing dan keterampilan (Suryadi dan Idris,2004:51).

4. Teori Evolusi

Menurut teori ini semua yang terjadi di jagat raya tidak berlangsung secara otomatis tetapi mengalami proses evolusi atau perubahan-perubahan yang berjalan secara perlahan tapi pasti, terus-menerus tanpa berhenti.

Kesetaraan gender merupakan gejala alam atau tuntutan yang menghendaki kesetaraan, yang harus direspon oleh umat manusia dalam rangka adaptasi dengan alam. Berdasarkan teori ini pembagian tugas dan tanggung jawab antara laki-laki dan perempuan pada zaman dahulu tidak pernah dipermasalahkan karena alamnya menuntut demikian. Sekarang tuntutan kesetaraan gender menjadi permasalahan yang menjadi perhatian manusia di seluruh dunia juga karena alam menuntut demikian disebabkan adanya perubahan kondisi sosial, ekonomi, dan budaya yang berlaku dimasyarakat yang memungkinkan peran laki-laki dan perempuan bisa sama atau dipertukarkan.

Pembelian impulsif merupakan pembelian yang tidak direncanakan secara khusus. Rook (Verplanken dan Herabadi, 2001:16) mengasosiasikan pembelian impulsif tersebut dengan pembelian yang dilakukan dengan tiba-tiba dan tidak direncanakan, dilakukan di tempat kejadian, dan disertai timbulnya dorongan yang besar serta perasaan senang dan bergairah.

Salah satu faktor yang mempengaruhi kecenderungan pembelian impulsif adalah karakteristik sosio-ekonomi dan karakteristik demografis. Karakteristik sosio-ekonomi yang mempengaruhi pembelian impulsif adalah uang saku, dimana Ling dan Lin (dalam Semuel 2007:28) mengatakan bahwa uang saku berhubungan positif dengan perilaku pembelian impulsif konsumen muda pada toko secara phisik atau offline. Karakteristik demografis yang mempengaruhi pembelian impulsif salah satunya adalah gender (Loudon dan Bitta, 1993:35).

Pada umumnya perempuan lebih sering membeli secara impulsif dibandingkan laki-laki. Kecenderungan pembelian impulsif terkait dengan peran gender seseorang yang dibedakan melalui pemilihan produk. Produk adalah segala sesuatu yang dapat ditawarkan ke suatu pasar untuk memenuhi keinginan dan kebutuhan, yang meliputi barang fisik, jasa, pengalaman, peristiwa, orang, tempat, property, organisasi dan gagasan (Kotler dalam Semuel, 2007)

\section{Kerangka Analisis}

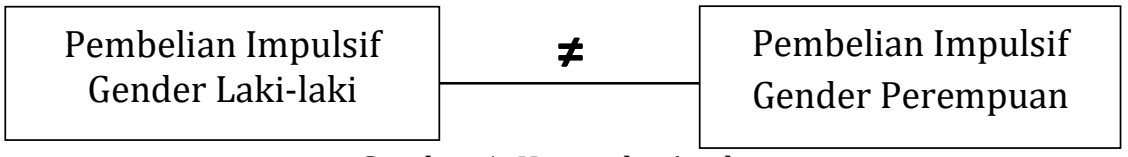

Gambar 1. Kerangka Analisis 


\section{Hipotesis}

Dalam penelitian ini diajukan hipotesis sebagai jawaban sementara terhadap permasalahan yang telah dikemukakan. Adapun hipotesis yang diajukan adalah "terdapat perbedaan pembelian impulsif ditinjau dari gender konsumen laki-laki dan perempuan pada Puncak Toserba Bengkulu.

\section{METODE PENELITIAN}

Jenis penelitian ini adalah penelitian komparatif. Penelitian ini dilakukan untuk membandingkan persamaan dan perbedaan dua atau lebih fakta-fakta dan sifat-sifat objek yang di teliti berdasarkan kerangka pemikiran tertentu. Metode pengambilan sampel digunakan metode purposive random sampling.

\section{HASIL PENELITIAN DAN PEMBAHASAN} Pembelian Impulsif Gender Laki-laki

Tabel 2. Tanggapan Responden Gender Laki-laki terhadap Pembelian Impulsif

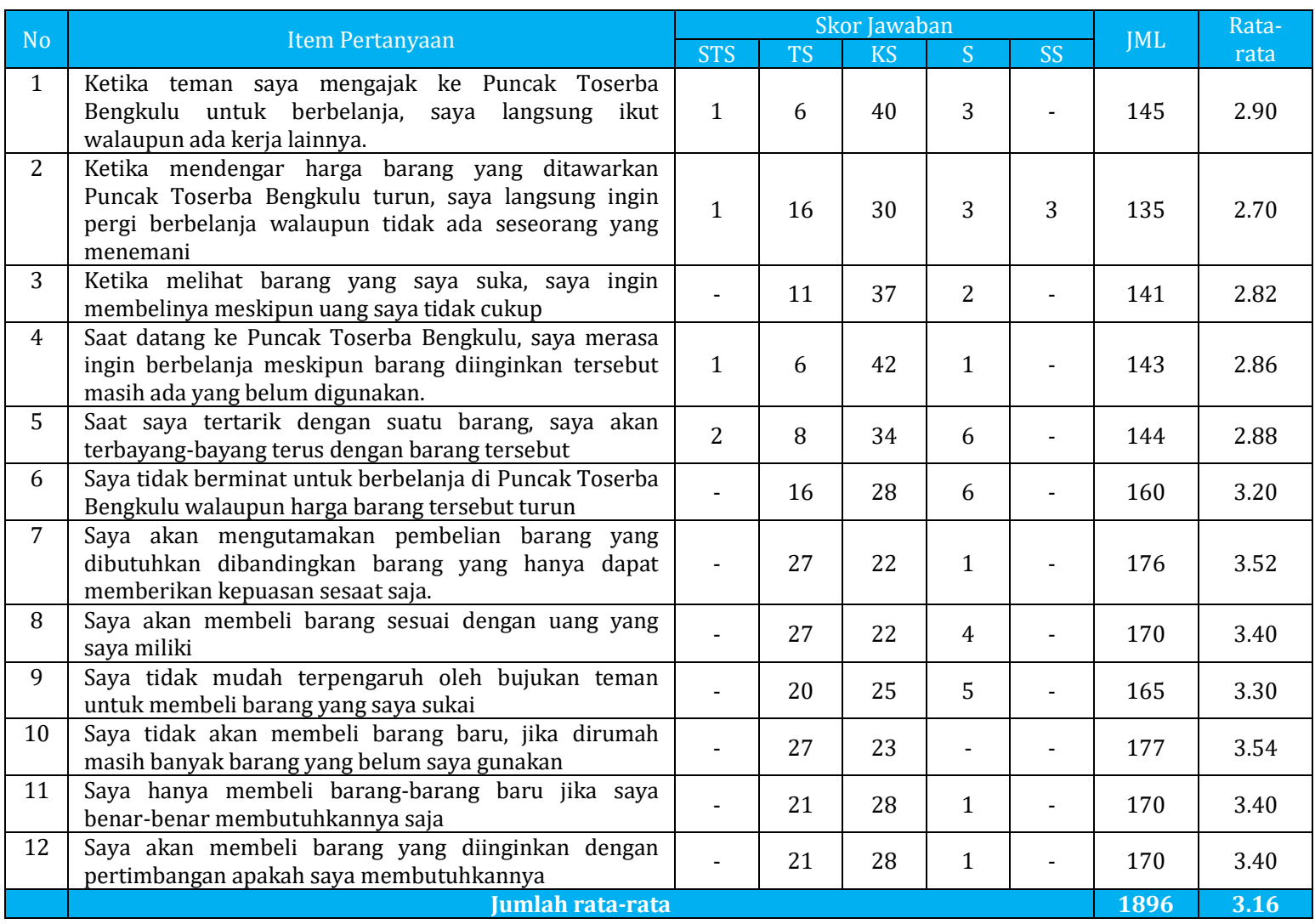

Sumber: Hasil Penelitian, data diolah, 2017

Keterangan:

$\begin{array}{ll}4.21-5.00 & \text { Sangat tinggi } \\ 3.41-4.20 & \text { Tinggi } \\ 2.61-3.40 & \text { Sedang } \\ 1.81-2.60 & \text { Rendah } \\ 1.00-1.80 & \text { Sangat rendah }\end{array}$

Berdasarkan tabel 2, diketahui nilai rata-rata pembelian impulsif dari kelompok gender lakilaki sebesar 3.16 teletak pada interval penilaian antara 2.61 - 3.40 dengan kategori sedang, artinya pembelian impulsif konsumen gender laki-laki pada Puncak Toserba Bengkulu dalam kategori sedang. 


\section{Pembelian Impulsif Gender Perempuan}

Tabel 3. Tanggapan Responden Gender Perempuan terhadap Pembelian Impulsif

\begin{tabular}{|c|c|c|c|c|c|c|c|c|}
\hline \multirow{2}{*}{ No } & \multirow{2}{*}{ Item Pertanyaan } & \multicolumn{5}{|c|}{ Skor Jawaban } & \multirow{2}{*}{$\mathrm{JML}$} & \multirow{2}{*}{$\begin{array}{l}\text { Rata- } \\
\text { rata }\end{array}$} \\
\hline & & STS & TS & $\mathrm{KS}$ & S & SS & & \\
\hline 1 & $\begin{array}{l}\text { Ketika teman saya mengajak ke Puncak Toserba } \\
\text { Bengkulu untuk berbelanja, saya langsung ikut } \\
\text { walaupun ada kerja lainnya. }\end{array}$ & - & 5 & 42 & 3 & - & 148 & 2.96 \\
\hline 2 & $\begin{array}{l}\text { Ketika mendengar harga barang yang ditawarkan } \\
\text { Puncak Toserba Bengkulu turun, saya langsung } \\
\text { ingin pergi berbelanja walaupun tidak ada } \\
\text { seseorang yang menemani }\end{array}$ & - & 11 & 36 & 3 & - & 142 & 2.84 \\
\hline 3 & $\begin{array}{l}\text { Ketika melihat barang yang saya suka, saya ingin } \\
\text { membelinya meskipun uang saya tidak cukup }\end{array}$ & - & 6 & 40 & 4 & - & 148 & 2.96 \\
\hline 4 & $\begin{array}{l}\text { Saat datang ke Puncak Toserba Bengkulu, saya } \\
\text { merasa ingin berbelanja meskipun barang } \\
\text { diinginkan tersebut masih ada yang belum } \\
\text { digunakan. }\end{array}$ & - & 2 & 45 & 3 & - & 151 & 3.02 \\
\hline 5 & $\begin{array}{l}\text { Saat saya tertarik dengan suatu barang, saya akan } \\
\text { terbayang-bayang terus dengan barang tersebut }\end{array}$ & 2 & 6 & 35 & 7 & - & 147 & 2.94 \\
\hline 6 & $\begin{array}{l}\text { Saya tidak berminat untuk berbelanja di Puncak } \\
\text { Toserba Bengkulu walaupun harga barang } \\
\text { tersebut turun }\end{array}$ & 4 & 14 & 28 & 4 & - & 168 & 3.36 \\
\hline 7 & $\begin{array}{l}\text { Saya akan mengutamakan pembelian barang yang } \\
\text { dibutuhkan dibandingkan barang yang hanya } \\
\text { dapat memberikan kepuasan sesaat. }\end{array}$ & 4 & 27 & 19 & - & - & 185 & 3.70 \\
\hline 8 & $\begin{array}{l}\text { Saya akan membeli barang sesuai dengan uang } \\
\text { yang saya miliki }\end{array}$ & 3 & 28 & 18 & 1 & - & 183 & 3.66 \\
\hline 9 & $\begin{array}{l}\text { Saya tidak mudah terpengaruh oleh bujukan } \\
\text { teman untuk membeli barang yang saya sukai }\end{array}$ & 5 & 17 & 24 & 4 & - & 173 & 3.46 \\
\hline 10 & $\begin{array}{l}\text { Saya tidak akan membeli barang baru, jika } \\
\text { dirumah masih banyak barang yang belum saya } \\
\text { gunakan }\end{array}$ & 4 & 24 & 22 & - & - & 182 & 3.64 \\
\hline 11 & $\begin{array}{l}\text { Saya hanya membeli barang-barang baru jika saya } \\
\text { benar-benar membutuhkannya saja }\end{array}$ & 4 & 16 & 24 & 3 & - & 174 & 3.48 \\
\hline 12 & $\begin{array}{l}\text { Saya akan membeli barang yang diinginkan } \\
\text { dengan pertimbangan apakah saya } \\
\text { membutuhkannya }\end{array}$ & - & 22 & 27 & 1 & - & 171 & 3.42 \\
\hline & Jumlah rata-r & & & & & & 1972 & 3.29 \\
\hline
\end{tabular}

Sumber: Hasil Penelitian, data diolah, 2017.

Keterangan:

$\begin{array}{ll}4.21-5.00 & \text { Sangat tinggi } \\ 3.41-4.20 & \text { Tinggi } \\ 2.61-3.40 & \text { Sedang } \\ 1.81-2.60 & \text { Rendah } \\ 1.00-1.80 & \text { Sangat rendah }\end{array}$

Berdasarkan tabel 3, diketahui nilai rata-rata pembelian impulsif dari kelompok gender perempuan sebesar 3.29 teletak pada interval penilaian antara 2.61 - 3.40 dengan kategori sedang, artinya pembelian impulsif konsumen gender perempuan pada Puncak Toserba Bengkulu dalam kategori sedang.

\section{Pengujian Hipotesis}

Pengujian hipotesis untuk melihat adanya perbedaan pembelian impulsif ditinjau dari gender laki-laki dan perempuan pada Puncak Toserba Bengkulu dalam penelitian ini menggunakan alat analisis independen samples $t$ tes. Independen samples $t$ tes digunakan untuk mengetahui ada atau tidaknya perbedaan rata-rata antara dua kelompok sampel yang tidak berhubungan. Asumsi dasar yang harus dipenuhi adalah adanya kesamaan varian (homogenitas).

Langkah pertama adalah melakukan uji kesamaan varian (homogenitas) dengan $\mathrm{F}$ tes (Levene's Test), artinya jika varians sama, maka uji t menggunakan Equal Variances Assumsed (diasumsikan varian sama) dan jika varian berbeda menggunakan Equal Variances Not Assumed (diasumsikan varian berbeda) langkah-langkah uji kesamaan varian (homogenitas) dengan uji F sebagai berikut: 
Ho: diterima jika $\mathrm{F}_{\text {sig }}>0,05$ artinya kedua varian sama

Ha: ditolak jika $\mathrm{F}_{\text {sig }}<0,05$ artinya kedua varian berbeda

Tabel 4. Independent Samples Test

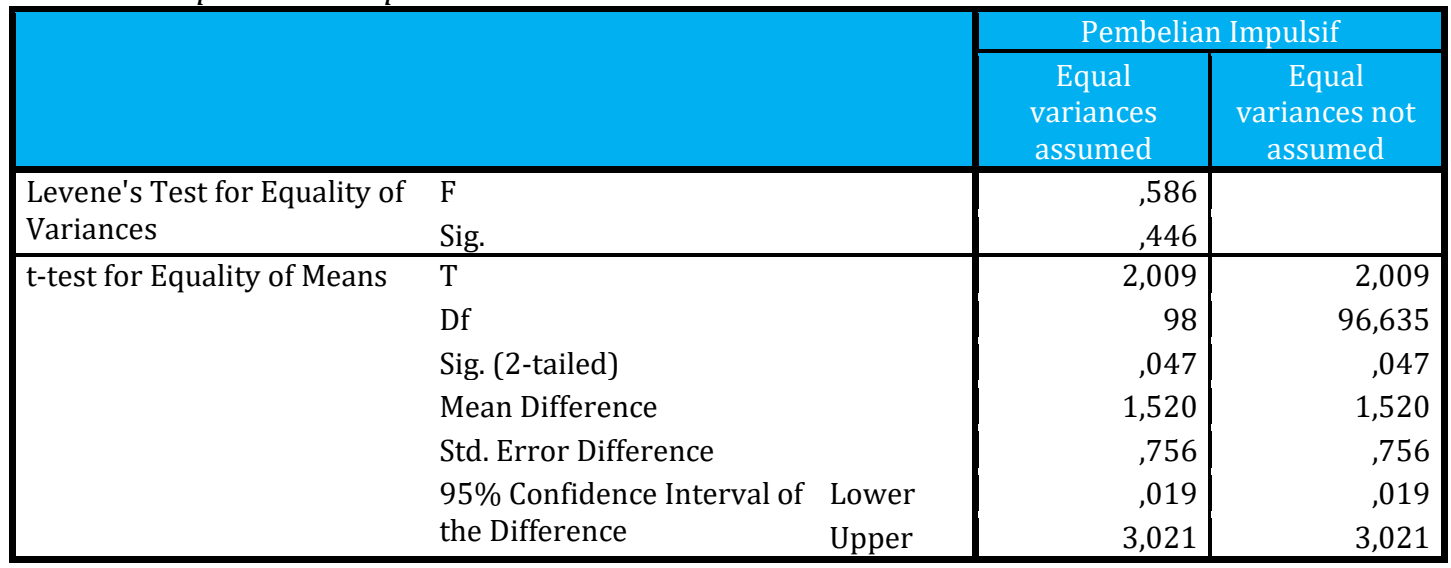

Sumber: Hasil Penelitian, data diolah, 2017

Berdasarkan tabel 4 yang telah diolah menggunakan SPSS, dapat diketahui nilai $F_{\text {sig }}(0,446)>0,05$. Maka Ha diterima, artinya kedua varian adalah sama, dengan demikian model yang digunakan pada uji $\mathrm{t}$ (Independent samples $t$ tes) adalah Equal Variances Assumed (diasumsikan varian sama).

Selanjutnya dilakukan uji t, dari tabel 4 diketahui nilai tsig pada uji dua sisi sebesar 0,047 jika dibandingkan dengan $\alpha=0,05$ maka $t_{\text {sig }}(0,047<0,05)$ maka Ha diterima berarti ada perbedaan yang signifikan antara pembelian impulsif gender laki-laki dan gender perempuan pada Puncak Toserba Bengkulu.

Berikut dijelaskan perbedaan rata-rata antara pembelian impulsif gender laki-laki dan gender perempuan pada Puncak Toserba Bengkulu:

Tabel 5. Group Statistics: Impulsif Buying

\begin{tabular}{|ll|r|r|r|r|}
\hline & Gender & N & Mean & Std. Deviation & Std. Error Mean \\
\hline Pembelian Impulsif & Perempuan & 50 & 39,44 & 4,001 &, 566 \\
& Laki-laki & 50 & 37,92 & 3,550 &, 502 \\
\hline
\end{tabular}

Dari tabel 5 yang telah diolah menggunakan SPSS terlihat bahwa rata-rata (mean) pembelian impulsif gender perempuan sebesar 39,44 sedangkan pembelian impulsif gender laki-laki sebesar 37,92, artinya bahwa rata-rata pembelian impulsif gender perempuan lebih tinggi daripada pembelian impulsif gender laki-laki. Perbedaan rata-rata kedua kelompok (mean diference) sebesar 1,520 berkisar antara 0,019 sampai 3,021 .

Hasil penelitian yang telah dilakukan menunjukkan bahwa ada perbedaan yang signifkan antara pembelian impulsif gender laki-laki dan gender perempuan pada Puncak Toserba Bengkulu dengan perbandingan $t_{\text {sig }}(0,047)<\alpha(0,05)$. Perbedaan rata-rata kedua kelompok tersebut sebesar 1,520 berkisar antara 0,019 sampai 3,021.

Pembelian impulsif merupakan pembelian yang tidak direncanakan secara khusus. Rook dalam Verplanken dan Herabadi (2001:16) mengasosiasikan pembelian impulsif tersebut dengan pembelian yang dilakukan dengan tiba-tiba dan tidak direncanakan, dilakukan di tempat kejadian, dan disertai timbulnya dorongan yang besar serta perasaan senang dan bergairah.

Salah satu faktor yang mempengaruhi kecenderungan pembelian impulsif adalah karakteristik sosio-ekonomi dan karakteristik demografis. Karakteristik sosio-ekonomi yang mempengaruhi pembelian impulsif adalah uang saku, dimana Ling dan Lin (dalam Semuel 2007:28) mengatakan bahwa uang saku berhubungan positif dengan perilaku pembelian impulsif konsumen muda pada toko secara phisik atau offline. Karakteristik demografis yang mempengaruhi pembelian impulsif salah satunya adalah gender (Loudon dan Bitta, 2003:35).

Pada umumnya perempuan lebih sering membeli secara impulsif dibandingkan laki-laki. Kecenderungan pembelian impulsif terkait dengan peran gender seseorang yang dibedakan melalui pemilihan produk. Produk adalah segala sesuatu yang dapat ditawarkan ke suatu pasar untuk memenuhi 
keinginan dan kebutuhan, yang meliputi barang fisik, jasa, pengalaman, peristiwa, orang, tempat, property, organisasi dan gagasan (Kotler dalam Semuel, 2007).

\section{KESIMPULAN}

Berdasarkan hasil dan pembahasan data penelitian dapat ditarik kesimpulan, yaitu : ada perbedaan yang signifikan antara pembelian impulsif gender laki-laki dan gender perempuan pada konsumen Puncak Toserba Bengkulu dengan perbandingan $t_{\text {sig }}(0,047)<\alpha(0,05)$. Perbedaan rata-rata kedua kelompok tersebut sebesar 1,520 berkisar antara 0,019 sampai 3,021.

\section{SARAN}

Penelitian ini menemukan bahwa kecenderungan pembelian impulsif khususnya konsumen gender perempuan, jadi diharapkan kepada perusahaan dapat melakukan strategi-strategi pemasaran yang dapat membuat konsumen semakin tertarik membeli produk dengan cara menampilkan iklan yang menarik di media massa, pemasaran langsung baik secara offline maupun online, kebijakan harga, mengatur posisi barang yang akan dipamerkan, dan berbagai usaha promosi lainnya. Bagi peneliti selanjutnya diharapkan dapat memberikan hasil penelitian yang lebih lengkap dan akurat dan dapat menggabungkan beberapa faktor demografis lain yang dapat mempengaruhi pembelian impulsif seperti budaya, perkawinan, penghasilan, pekerjaan dan pendidikan.

\section{DAFTAR PUSTAKA}

Amir, M. Taufiq. 2004. Manajemen Ritel: Panduan Lengkap Pengelolaan Toko Modern Edisi Pertama. Jakarta. PT Ikrar Mandiriabadi.

Bagus, Lorens. 2002. Kamus Filsafat. Jakarta. PT Gramedia Pustaka Utama.

Ditmar, H. et al. 1995. Gender Identity and Material Symbols; Objects and Decisions Consideration in Impulse Purchases. http://www.kent.ac.uk/ESCR/iarep.html,

Daryanto dan Setyobudi Ismanto. 2014. Konsumen dan pelayanan prima. Yogyakarta. Gava Media

Dony. 2007. Pembelian Terencana dan Tak Terencana. http://donydw.wordpress.com/,

Jarwanto. PS dan Subagyo Pangestu. 2009. Statistik Induktif. Yogyakarta. BPFE

Engel, J., and Blackwell, R. 1995. Consumer Behaviour. Dryden Press, Chicago, IL.

Fika dan Sumaryono. 2008. Pembelian Impulsif Ditinjau Dari Kontrol Diri dan Jenis Kelamin pada Remaja. Jurnal Psikologi Proyeksi. Vol.3(1), 46-57.

Fitri, R. A. 2006. Terlena dalam Nikmatnya Belanja. Koran Suara Pembaruan. Diambil secara Online pada http://groups.google.com.np/group/alt.sci.tech. indonesian/msg/e061975f8b58c5a9,

Handayani, Trisakti dan Sugiarti. 2001. Konsep dan Teknik Penelitian Gender. Malang. Pusat Studi Wanita dan kemasyarakatan

Kacen, Jacqueline J., \& Hess, James D. 2007. The comparative influence of consumer, producer and retailer factors on impulsive buying. Journal of consumer psychology.

Kotler dan Armstrong. 2003. Dasar-dasar Pemasaran. Jakarta. PT Indeks Gramedia.

Kotler, Philip dan Keller Kevin Lane. 2008. Dasar-Dasar Pemasaran. Alih Bahasa Benjamin Moelan. Jakarta. PT. Indeks.

Loudon, D. L. \& Bitta, A. J. 2003. Consumer Behavior Concept and Application( ${ }^{4}$ th edition). Singapore McGraw-Hill

Murniati, Nunuk. 2004. Getar Gender, Buku Pertama (Perempuan Indonesia dalam Perspektif Sosial, Ekonomi, Politik,Hukum dan HAM). Jakarta. Indonesiatera.

Schiffman dan Kanuk, 2008. Perilaku Konsumen. Alih Bahasa oleh Zoelkifli Kasip. Jakarta. PT. Indeks Gramedia

Semuel. Hatane. 2007. Pengaruh Stimulus Media Iklan, Uang Saku, Usia, Dan Gender Terhadap Kecenderungan Perilaku Pembelian Impulsif (Studi Kasus Produk Pariwisata). Diambil secara online Samy@peter.petra.ac.id

Setiadi, Nugroho, 2003. Perilaku Konsumen. Jakarta. Prenada Media Group.

Sugiyono, 2008. Metode Penelitian Bisnis. Bandung. Alfabeta

Suryadi, A. Idris, E. 2004. Kesetaraan Jender dalam Bidang Pendidikan.Bandung. PT. Genesindo.

Tambunan, R. 2007. Remaja dan Perilaku Konsumtif. Diambil secara online pada http://www.duniaesai.com/psikologi/psi7.html

Verplanken. B. \& Herabadi A. 2001. Individual Differences In Impulse Buying Tendency Feeling And No Thinking. European Journal of Personality.

Winardi. 2004. Manajemen Perilaku Organisasi. Jakarta. Pustaka Binaman Pressindo. 